\title{
Sandstone Hammer in a Diluvial Deposit at Macclesfield.
}

Dear Sir,-I send a stone-hammer for your inspection, which was found a short time ago near Siddington, about six miles to the west of this town, in a boggy piece of ground, about 2 yards below the surface, and upon the Red Marl. Its length is $7 \frac{1}{3}$ inches, breadth $3 \frac{1}{2}$, thickness $2 \frac{1}{2}$, hole for the handle $1 \frac{3}{8}$; one end is rounded, the other vertically wedge-shaped; and it is of superior workmanship, having been probably made at the close of the stone-period. In the second volume of the 'Geologist' there are several engravings of sandstone-hammers, but none, I think, similar to the one I have sent you. If you think this of sufficient interest, perhaps you may be induced to give a drawing of it in your next number. In composition it appears to partake in character with some of the lower grits which crop out about two miles distant southward, with a north-westerly dip. All the different beds of grit below the true coal-measures are well developed in this locality, and their basement or Gosedale series are in general very fine-grained, hard, and compact, and produce excellent material for the roads. The Millstone Grit of this district possibly attains a depth of more than 3000 feet. One or two of the upper beds of grit contain thin seams of poor coal, which belong to the lower measures, and are only occasionally worked, not being remunerative; they are not very fossiliferous. It appears rather strange that the natives of this part of the country during the prehistoric or stone age should have resorted to the fabrication of sandstone-hammers, when if the question of durability were at issue, that qualification was always obtainable, since the whole of this neighbourhood was thickly strewed during the glacial period with almost every variety of the hardest igneous rocks, interspersed with hard sandstones and rounded limestones of various geological periods. The advancement of agriculture has now almost obliterated those deposits from the surface of the lower levels and plains, but on higher ground this is by no means the case. The moorlands and elevated districts are still dotted by boulders in every direction, and among some fields about four miles from here eastward, upon an isolated patch of ground some acres in extent and at an elevation of 1000 feet, a remarkable colony of those erratics is still extant. Blocks of quartz-rock, basalts, various granites, greenstones, porphyries, etc.,-more or less grooved, scratched, or smoothed,-lie scattered about in wild and chaotic profusion. There they remain in their primitive position, unaffected by time, untouched by the hand of man, and represent perhaps a true aspect of this part of the country immediately after its last upheaval above the waste of waters. At a mile and a half to the south of the scene just described there is an extensive outlier of the drift, which contains marine shells of arctic type, about 1200 feet above the sea-level. It is chiefly composed of coarse sand and gravel, and in one place has an escarpment of 30 feet. This rests upon a plateau or terrace of shale and grit, which denotes the ancient bed of a swift stream, that has now cut its way almost perpendicularly through the latter strata to a depth of 20 feet. A bout the middle of the section or escarpment there is a thick bed crowded with large water-worn pebbles and pieces of rough sandstone or grit; and this is also the shell-bed. These have probably been tranquilly deposited by stranded ice, after floating hundreds of miles from their Scandinavian home. The whole of Macclesfield is built upon the drift at an elevation of more than 500 feet. On the eastern side of the town there are two or three distinct terraces or former levels of the river many feet above its present bed, and the superficial sand and gravel overlying the boulder clay contain quantities of minute fragments of boreal sheils. 
The study of the glacial periods may be considered a most sublime and interesting subject, connected as it is so intimately with the history and antiquity of man. The cataclysms and many other physical phenomena which occurred in these latitudes are amazing; and perhaps it were a misfortune, for the sake of truth and the advancement of science, that the genus Homo existed during the above periods in a low and debased form of organization. For countless ages he trod the earth, in all climes, a wandering savage; and almost the only records left of him as works of art or design, which serve to distinguish him, in point of intelligence, from the brute creation, are a few specimens of rudely-chipped flint: instruments, that were used by him alike for offence, defence, hunting, and other purposes.

From later researches, if the conclusions of the antiquarian and geologist are to be accepted, it would appear that we must remore still further back in geological time the chronology of the human epoch. One species of a low form is mentioned as having become extinct, while it is affirmed that the genus was represented by species in the Plicene and even the Miocene period. Towards the Eocene beds of Suffolk, this vexata quastio seems to be trending; since in them, according to a certain theory, there is to be found a fossil that may be the earliest prototype of the Bimana.

Macclesfield, January 5, 1864. I am, dear Sir, yours respectfully, J. D. SAINTER.

\section{PROCEEDINGS OF GEOLOGICAL SOCIETIES.}

East Kent Natural History Societr.-At an evening meeting, held at Canterbury, on November 24th, a lecture "On the Tertiary Beds of Kent" was delivered by W. Whitaker, B.A., F.G.S., of the Geological Survey of Great Britain, of which the following is an abstract :-

The sedimentary rocks are divided by geologists into three groups, Primary, Secondary, and Tertiary. The formations belonging to the first and oldest of these periods do not occur in the south-east of England, but are confined to the north and west. Of the Secondary period, only the higher formations (the Wealden and Cretaceous rocks) crop out to the surface in Kent. Of the Tertiary beds, on the contrary, only the lower divisions are known for certain to occur in this county, where, however, they are better developed and exposed than any where else.

Before treating of the lertiary formations, it is needful to say a few words of the underlying Chalk, the highest of our Secondary rocks. It is a sea-deposit, rich in fossils, of which many are such as must have lived at a great depth and apparently in the sea of a warm climate. From the fact that the fossils of the overlying beds are altogether of different kinds from those of the Chalk, it has been inferred that those beds were not at once deposited on the Chalk, but that after the deposition of the latter, a long time passed away before other beds were formed over it.

'The Kentish Tertiaries belong to the "Eocene," or Lower Tertiary series; and consist, in ascending order, of the Thanet beds, the Woolwich beds, and the basement bed of the London Clay,-grouped together by Prestwich (to whom we owe nearly all our knowledge of these beds) under the name of "Lower London Tertiaries,"-the London Clay and the Lower Bagshot Sand.

VOL. VII. 